\title{
Boxwood Leafminer Monarthropalpus flavus (Schrank) (Insecta: Diptera: Cecidomyiidae) ${ }^{1}$
}

\author{
Balwinder Kaur and Adam Dale ${ }^{2}$
}

\section{Introduction}

The first planting of boxwoods in North America were of the common boxwood (Buxus sempervirens) and are believed to have been on a plantation in Shelter Island, New York in 1653 by Nathaniel Sylvester (Batdorf 1994). Since its introduction, this species has become among the most popular shrub produced by nurseries and planted by homeowners in eastern North America.

Boxwood continues to be one of the most popular shrubs produced by nurseries and planted in urban and residential landscapes in the United States (Figure 1). This evergreen plant successfully grows in full sun to partial shade environments and provides green foliage year-round (Butzler 2017). Boxwood can be pruned heavily into different shapes or forms, making it a highly desirable plant for hedges, formal gardens, and sites where specific plant forms are required (Batdorf 1994).

Unfortunately, boxwoods are attacked by multiple pests such as boxwood blight (Calonectria pseudonaviculata), boxwood psyllids (Psylla buxi), boxwood spider mites (Eurytetranychus buxi), and the boxwood leafminer (Monarthropalpus flavus (Schrank)). Boxwood leafminer is a yellow to orange-red gnat-like fly (Smith et al. 1928), whose maggots (larvae) can cause severe damage to boxwood (Buxus spp.) trees and shrubs across the United
States (Hoover 2001). This small fly is native to Europe and was first detected as a pest of boxwood in the United States in 1910 (Felt 1910).

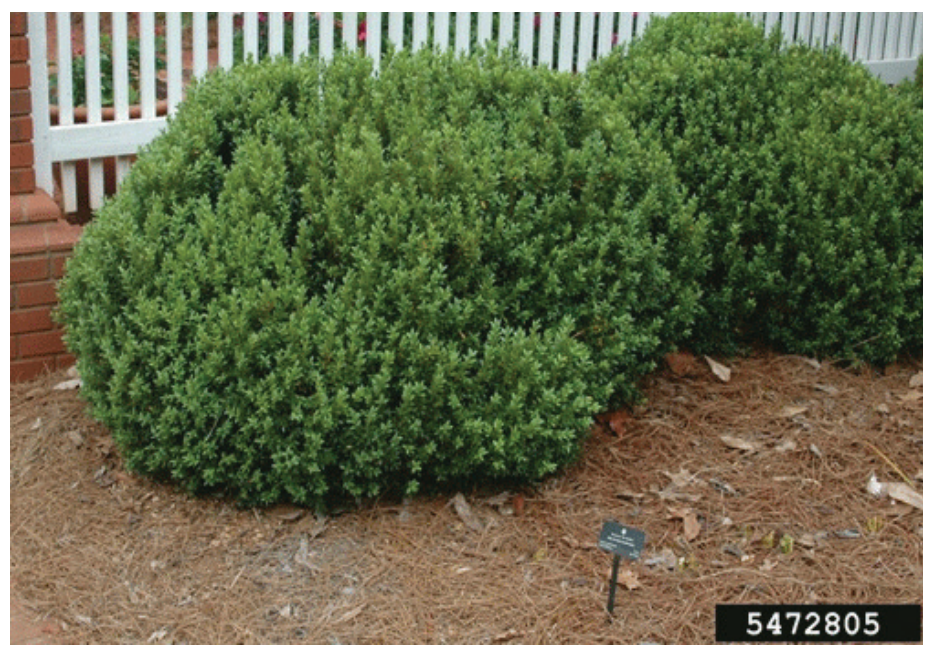

Figure 1. Hedged Buxus sp. shrubs in a residential landscape. Credits: Karan A. Rawlins, University of Georgia

\section{Synonymy}

The species, Monarthropalpus flavus, was originally described as Scathopse flava Geoffroy in 1764 and has changed names multiple times since. Several synonyms exist, the most common of which is Monarthropalpus buxi (Barnes 1948, Perju et al. 2001); however, the currently accepted name is Monarthropalpus flavus.

1. This document is EENY-752, one of a series of the Entomology and Nematology Department, UF/IFAS Extension. Original publication date April 2020. Visit the EDIS website at https://edis.ifas.ufl.edu for the currently supported version of this publication. This document is also available on the Featured Creatures website at http://entnemdept.ufl.edu/creatures/.

2. Balwinder Kaur, UF/IFAS Everglades Research and Education Center; and Adam Dale, Entomology and Nematology Department; UF/IFAS Extension, Gainesville, FL 32611.

The Institute of Food and Agricultural Sciences (IFAS) is an Equal Opportunity Institution authorized to provide research, educational information and other services

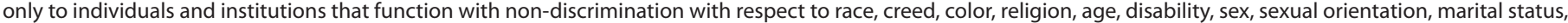

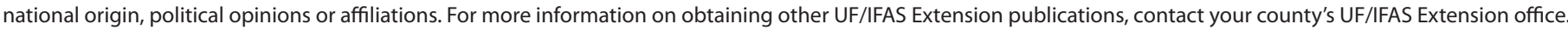
U.S. Department of Agriculture, UF/IFAS Extension Service, University of Florida, IFAS, Florida A \& M University Cooperative Extension Program, and Boards of County Commissioners Cooperating. Nick T. Place, dean for UF/IFAS Extension. 
- Tipula flava (Schrahangesnk 1776)

- Cecidomyia buxi (Laboulbène 1873)

- Monarthropalpus buxi in (Rübsaamen 1892)

\section{Distribution}

The boxwood leafminer is widespread in continental Europe (Pitkin 2017) but is rarely damaging in its native range.

The boxwood leafminer is suspected to have arrived in North America in potted boxwood shrubs in the mid$1600 \mathrm{~s}$, around the same time the plants were introduced (Gagne 1989). Despite its suspected early introduction, it was not reported as a pest in United States until the early 1900s when it was found in Kingston, Rhode Island by Prof. A. E. Stene in a boxwood shrub (Buxus sempervirens) (Felt 1910). It is now distributed throughout the United States from the Pacific coast to the Atlantic coast (Brewer et al 1984).

\section{Description and Biology}

Larvae of boxwood leafminer are yellowish-white to green and are about $3 \mathrm{~mm}$ (0.12 inches) long (Hoover 2001). Pupae are whitish to dark yellow, and about $3 \mathrm{~mm}(0.12$ inches) in length. Adults are orange-yellow to red, approximately $2.5 \mathrm{~mm}$ ( 0.1 inches) long, gnat-like flies (Figure 2) (Russell 2013). Adults have 14 antennal segments. Upon casual observation, adult leafminers are often described as mosquito-like insects swarming in boxwoods. During severe infestations, leafminer damage is highly visible on healthy bright green boxwood foliage.

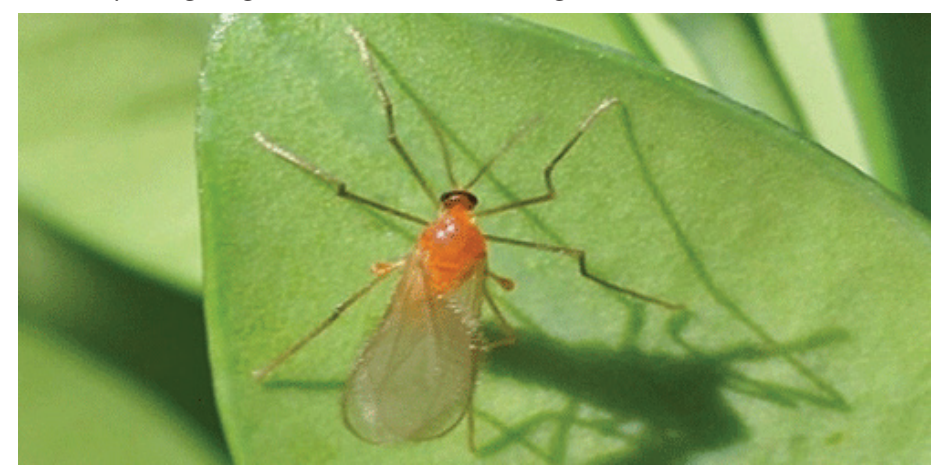

Figure 2. Monarthropalpus flavus (Schrank) adult resting on a Buxus sp. leaf.

Credits: Joe Boggs, The Ohio State University

In spring, females use their needle-like ovipositor to deposit eggs into the underside of recently expanded leaf tissue. On average, a female will lay about 20 eggs per leaf (Hamilton 1925). After 14 to 21 days, these eggs will hatch into legless maggots or larvae and begin feeding on leaf tissue from within the leaf (Figure 3) (Russell 2013).

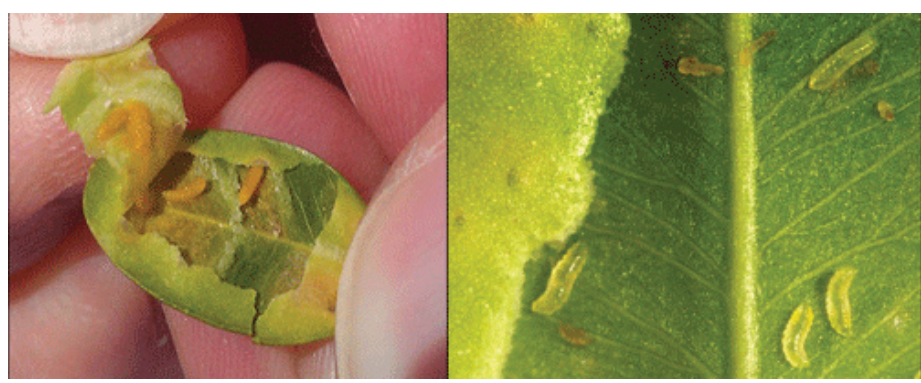

Figure 3. (Left) Monarthropalpus flavus (Schrank) maggots exposed from within a Buxus sp. leaf. (Right) Microscopic view of Monarthropalpus flavus (Schrank) maggots.

Credits: Left: Steve Frank, North Carolina State University; Right: Nancy Gregory, University of Delaware. Bugwood.org

Larvae feed throughout the summer and fully develop into pupae by the winter (Figure 4) at which point they tend to go dormant within the leaf tissue (Barnes 1948). Adults emerge in the spring as temperatures warm and the spring flush of boxwood leaves emerge (Russell 2013).

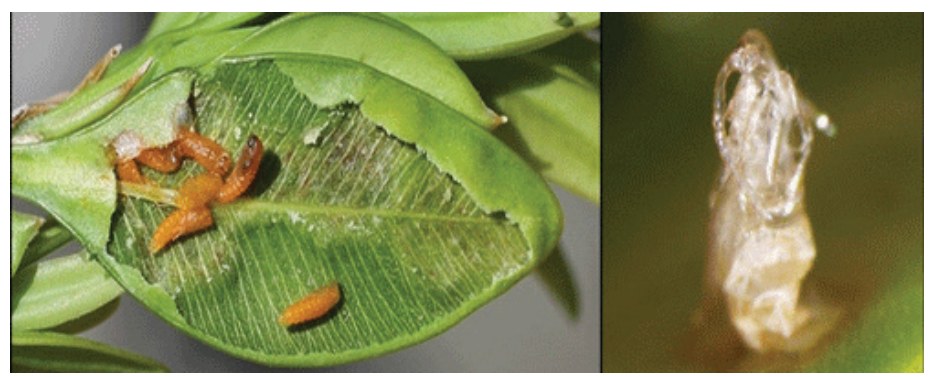

Figure 4. (Left) Boxwood leafminer, Monarthropalpus flavus

(Schrank), pupae exposed after removing external leaf layer. (Right) Pupal exuviae (empty pupal case) of emerged boxwood leafminer, Monarthropalpus flavus (Schrank).

Credits: Left: Joe Boggs, The Ohio State University Extension; Right: Bruce Watt, University of Maine. Bugwood.org

The adult emergence period typically occurs in the spring as temperatures warm and lasts only about two weeks once it begins (Barnes 1984). Adults emerge through circular windows on blisters, leaving behind a pupal case (exuvia), which remains protruding from the lower surface of the previously infested leaf (Figure 4) (Brewer et al 1984). Adult emergence is synchronized with sunlight level, resulting in more adults emerging during early morning hours (Brewer 1981). These midges have one generation per year and complete their entire juvenile development within the leaf before emerging as adults (Brewer et al. 1984).

\section{Hosts}

Boxwood leafminer is a monophagous species (feeds on one genus of plants), feeding only on boxwood (Buxus spp.) (Soporan et al. 2012). It heavily attacks common boxwood (Buxus sempervirens) and related species, including round leaf boxwood, Buxus roduntifolia; box Bullata (Buxus bullata), and balearica boxwood (Buxus balearica) (Soporan et 
al. 2015). Boxwood leafminer commonly attacks boxwood species grown in historic gardens and arboretums across the United States as well as residential plantings, resulting in plant damage and subsequent pest control efforts.

\section{Economic Importance}

Boxwood leafminer larvae mine or tunnel between upper and lower parts of leaf tissue causing irregular blisters on the lower surface and slight elevations on the upper surface of the leaf (Russell 2013). A leaf blister is a swollen or thickened area of a leaf, which on the surface often appears crinkled, yellow or brownish in color, and distorts the leaf structure. Early indications of attack include light green or yellow spots on the upper leaf surface (Barnes 1948). As damage progresses, irregular blisters in the form of olive green or brownish discolorations appear on the lower surface of the leaf (Figure 5). Since leaf blisters are a physical separation in the leaf's vascular tissue, it disrupts the flow of nutrients within the leaf resulting in premature leaf drop.

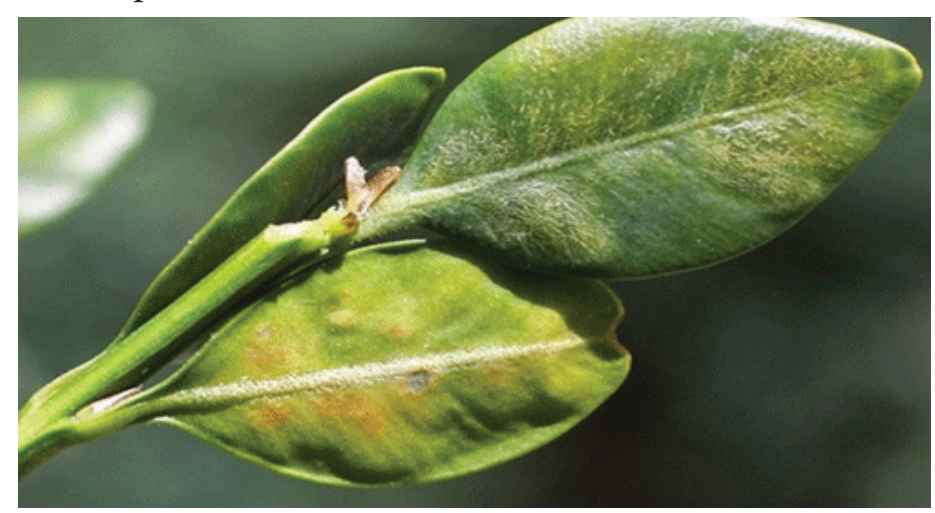

Figure 5. Boxwood leafminer, Monarthropalpus flavus (Schrank), mines and blisters along the upper and lower surfaces of leaves, respectively. Credits: Joe Boggs, The Ohio State University. Bugwood.org

Once larvae are fully developed, nearly transparent circular spots or windows appear on the lower surface of the leaf. Breaking open these blisters or windows with your thumbnail typically reveals two to six larvae within a single leaf. Infested leaves appear yellow, discolored, and are smaller than healthy leaves (Figure 6).

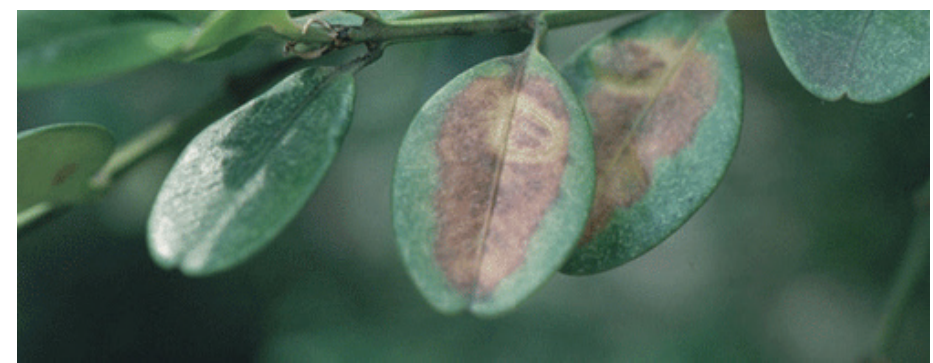

Figure 6. Discolored leaves from old blistering damage caused by boxwood leafminer, Monarthropalpus flavus (Schrank). Credits: Pennsylvania State University Department of Plant Pathology \& Environmental Microbiology Archives. Bugwood.org
During heavy infestations, boxwood leaves become severely damaged and turn brown, causing them to drop prematurely, leaving behind bare branches or entire plants (Figure 7). A severely infested plant usually dies after a year (Barnes 1948). Prolonged infestations of boxwood leafminer can cause branch dieback and make them more susceptible to damage from plant pathogens and adverse environmental conditions such as freezing, drought, and severe heat (Hoover 2001).

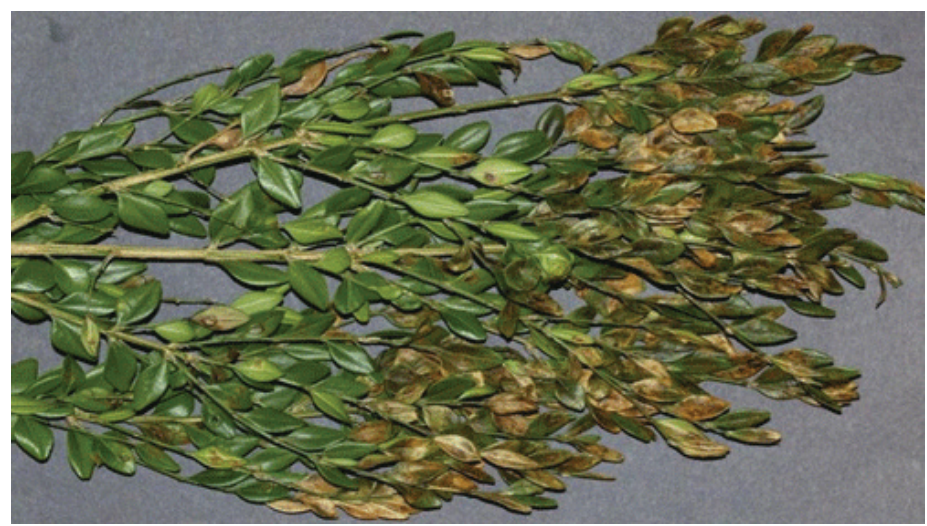

Figure 7. Severely infested foliage by boxwood leafminer, Monarthropalpus flavus (Schrank).

Credits: Bruce Watt, University of Maine. Bugwood.org

\section{Management Cultural Control}

The first step for managing boxwood leafminer begins with maintaining healthy vigorous plants with proper irrigation, fertilization, and pruning practices. Healthy plants are generally less susceptible to pest attack. Using boxwood leafminer-resistant plant varieties is an excellent integrated pest management tactic for long-term control.

\section{Cultivars of English boxwood, Buxus sempervirens, are} less susceptible to boxwood leafminer compared to other commonly used varieties. Dwarf forms such as Buxus microphylla are also resistant to the leafminer (d'Eustachio and Raupp 2001, Niemiera 2018) (Figure 8). Resistant Buxus spp. cultivars should be planted to minimize boxwood leafminer pressure and associated management needs (Raupp et al. 2004). Resistant cultivars include (Thurn et al. 2018):

- Buxus microphylla var. japonica

- Buxus microphylla 'Green pillow', 'Grace Hendrick Phillips'

- Buxus microphylla var. sinica 'Franklin's Gem'

- Buxus sempervirens 'Pendula, 'Argenteo-varigata, 'Handworthiensis,' 'Pyramidalis,' 'Suffruticosa', 'Vardar Valley', 'Justin Brouwers' 
- Buxus harlandi 'Richard'

- Buxus sinica var. insularis 'Nana'

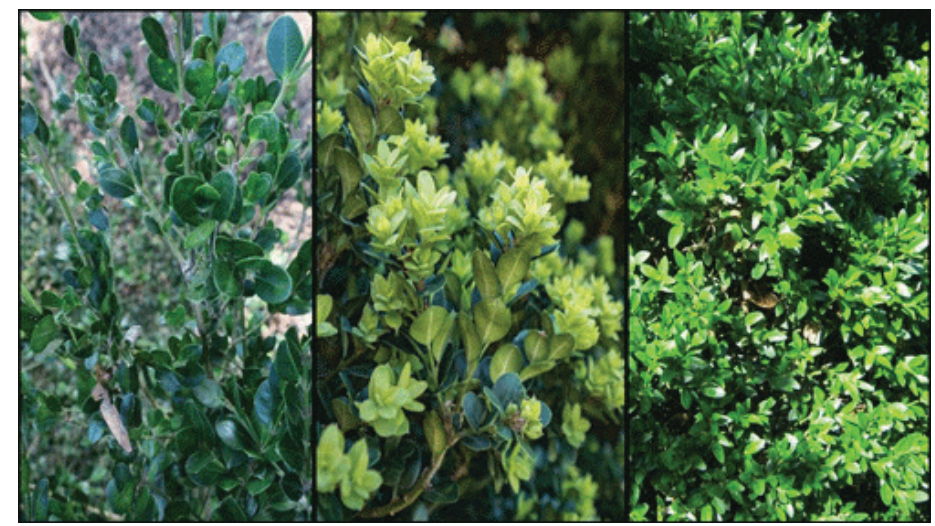

Figure 8. Boxwood cultivars resistant to boxwood leafminer, Monarthropalpus flavus (Schrank), attack. (left) Buxus microphylla var. japonica. (middle) Buxus sempervirens 'Vardar Valley'. (right) Buxus sinica var. insularis 'Justin Brouwers'.

Credits: Left: Maryann Debski, North Carolina State University, Bugwood Image ID 639172; Middle: Kristi Traynor, North Carolina State University, Bugwood Image ID 680730; Right: Maryann Debski. North Carolina State University, Bugwood Image ID 627035

\section{Mechanical Control}

If a leafminer infestation is detected, prune off the infested leaves or twigs while the larvae are still in the leaf tissue and dispose of them away from the site. This can effectively reduce the severity of localized infestations (Hoover 2001). Mechanically crushing the leaves to kill maggots is not practical due to the difficulty of detecting all infested leaves and the time required for the practice to be effective.

\section{Biological Control}

Several birds such as chickadees, warblers, nuthatches, and tufted titmice can hear pupae inside the leaf and peck at the boxwood leaves to extract the pupae (Batdorf 1994). Titmice can reduce boxwood leafminer populations; however, the pecking causes more damage to boxwood foliage than the insect itself (d'Eustachio 1999). Few reports of a parasitic wasp, Tetrastichus flora (Girault) (Hymenoptera: Eulophidae), in boxwood leafminer galleries have been recorded, but this insect is not available commercially nor recommended as a viable biological control tactic (Krombein et al. 1979).

\section{Chemical Control}

Adult leafminers emerge from leaves in the spring and are the most susceptible life stage to insecticides since they are not concealed within the leaf tissue. To maximize insecticide efficacy and leafminer control, synchronize pesticide applications with emergence of leafminer adults and new plant growth (Hoover 2001). To control early instar larvae, insecticides with systemic activity can be applied as a soil drench or injection. For example, some systemic insecticides such as imidacloprid have effectively reduced the number of larvae in boxwood leaves (d'Eustachio and Raupp 2011).

Boxwood leaves have a thick waxy cuticle. Adding surfactants in a foliar insecticide spray will help with adhesion of chemical molecules to the leaf surface of boxwood. For more questions related to boxwood leafminer and its control, consult your local UF/IFAS Extension office (http:// sfyl.ifas.ufl.edu/find-your-local-office/) and utilize up-todate UF/IFAS EDIS (https://edis.ifas.ufl.edu/) publications.

\section{Additional Resources}

Home Ornamentals: Insects of Trees, Shrubs, Annuals, and Perennials

Boxwood insect pests

The American Boxwood Society

Saunders Brothers Boxwood Guide

Photographic Guide of Boxwood Pests \& Diseases on Long Island

\section{Selected References}

Barnes H. F. 1948. Gall Midges of Economic Importance. Crosby, Lockwood, and Sons, London, UK. 184 pp.

Batdorf L. R. 1994. Boxwood Handbook. American Boxwood Society, Boyce, Virginia.

Brewer J. W. 1981. “The influence of light on emergence patterns of Monarthopalpus buxi (Lab.) (Diptera, Cecidiomiidae)." Acta Entomologica Bohemoslovaca. 78: 152-161.

Brewer J. W., Skuhravÿ V., Skuhravá M. 1984. “Biology, distribution and control of Monarthropalpus buxi (Laboulbéne) (Diptera, Cecidomyiidae)." Zeitschrift für Angewandte Entomologie 97: 167-175.

Cory E. N., Craham C. 1930. "Practicability of the hot water treatment for the boxwood leaf miner." Journal of Economic Entomology 23: 563-576. https://doi.org/10.1093/ jee/23.3.563

d'Eustachio G. 1999. Integrated management of the boxwood leafminer. M.S. Thesis. University of Maryland, College Park, MD, 83 pp. 
d'Eustachio G., Raupp M. 2001. "Application of systemic insecticides in relation to boxwood leafminer's life history." Journal of Arboriculture 27: 255-262.

d'Eustachio G., Raupp M. 2011. "Resistance of boxwood varieties to the boxwood leafminer, Monarthropalpus flavus (Schrank)." Journal of Environmental Horticulture 19: 153-157. https://www.hrijournal.org/doi/ pdf/10.24266/0738-2898-19.3.153

Felt E. P. 1910. "Recent observations upon European insects in America." Journal of Economic Entomology 3: 340-342. https://doi.org/10.1093/jee/3.4.340

Gagne R. 1989. The plant feeding gall midges of North America. Ithaca, NY: Comstock Publishing Associates.

Hamilton C. C. 1925. The boxwood leafminer. College Park, MD: The University of Maryland Agricultural Experiment Station.

Hoover G. A. 2001. Boxwood leafminer. Penn State College of Agricultural Sciences Research. https://ento.psu.edu/ extension/factsheets/boxwood-leafminer (13 April 2020)

Krombein K. V. 1979. Catalog of Hymenoptera in America North of Mexico. Vol. 2. Washington, D.C.: Smithsonian Institution Press 1: 1199-2209.

Niemiera A. X. 2018. Selecting landscape plants: Boxwoods. Virginia Cooperative Extension. https://www.pubs.ext. vt.edu/426/426-603/426-603.html. (13 April 2020)

Perju T., Ghizdavu I. 2001. Compendium of Agricultural Zoology. Publishing Romanian Academy, Bucharest 5: 273-274.

Pitkin B., Willem E., Plant C., Edmunds R. 2017. The leaf and stem mines of British flies and other insects (Coleoptera, Diptera, Hymenoptera and Lepidoptera). http://www. ukflymines.co.uk/. (13 April 2020)

Raupp M., Mars I. H., d'Eustachio G. 2004. "Integrated approaches for managing the boxwood leafminer, Monarthropalpus flavus." Acta Horticulturae 630: 57-63. doi:10.17660/ ActaHortic.2004.630.6

Russell H. 2013. Boxwood insect pests. Michigan State University Extension. https://www.canr.msu.edu/news/ boxwood_insect_pests. (13 April 2020)
Smith F. F., Fisher H. J., Guyton T. L. 1928. "Hot water immersion for boxwood leaf miner control." Journal of Economic Entomology 21:295-301. https://doi.org/10.1093/ jee/21.2.295

Soporan C., Oltean I., Florian T. 2012. “The Monarthopalpus buxi species population dynamics in Cluj County (Romania)." Bulletin University of Agricultural Sciences and Veterinary Medicine Cluj-Napoca. Agriculture 69(1).

Thurn M., Lamb E., Eshenaur B. 2018. Diseases and insect resistant ornamental plants: Buxus (Boxwood). https://hdl. handle.net/1813/56366.2. (13 April 2020) 